\title{
PENGEMBANGAN MODUL MATEMATIKA SMK BIDANG SENI, KERAJINAN, DAN PARIWISATA BERBASIS OPEN-ENDED PROBLEM SEBAGAI IMPLEMENTASI KTSP
}

\author{
Nelly Rhosyida ${ }^{1)}$, Jailani ${ }^{2)}$ \\ Prodi Pendidikan Matematika PPs UNY ${ }^{1)}$, Universitas Negeri Yogyakarta ${ }^{2)}$ \\ nelly.pmat2011@gmail.com ${ }^{1)}$, jailani@uny.ac.id ${ }^{2)}$
}

\begin{abstract}
Abstrak
Tujuan penelitian ini adalah untuk menghasilkan modul matematika SMK bidang seni, kerajinan, dan pariwisata berbasis open-ended problem. Penelitian ini merupakan penelitian pengembangan model four- $D$ Thiagarajan yang telah dimodifikasi, yang melalui tiga tahap yaitu pendefinisian, perancangan, dan pengembangan. Data kevalidan, kepraktisan, dan keefektifan berupa penilaian terhadap modul dianalisis dengan mengkonversi skor menjadi data kualitatif skala lima sedangkan data keefektifan berupa tes hasil belajar dianalisis dengan persentase ketuntasan belajar dan peningkatan hasil belajar yang dianalisis dengan $\mathrm{N}$-gain ternormalisasi. Tingkat kevalidan dapat dilihat dari penilaian dua ahli pembelajaran matematika yang menyatakan bahwa modul sangat valid. Tingkat kepraktisan dapat dilihat dari hasil penilaian guru dan siswa yang menyatakan modul sangat praktis untuk digunakan dalam pembelajaran matematika. Tingkat keefektifan dapat dilihat dari hasil pencapaian KKM siswa dan peningkatan hasil belajar yang menyatakan bahwa modul sangat efektif. Hal ini menunjukkan bahwa modul matematika SMK yang dikembangkan layak digunakan sebagai sumber belajar matematika SMK.
\end{abstract}

Kata Kunci: pengembangan, matematika, SMK, modul, open-ended problem

\section{DEVELOPING A MATHEMATICS MODULE FOR SMK OF ARTS, CRAFTS, AND TOURISM BASED ON OPEN-ENDED PROBLEM AS AN IMPLEMENTATION OF KTSP}

\begin{abstract}
This study aimed to develop a mathematics module based on open-ended problems as a good learning resourch for SMK. This study is developmental research, applying the modified four-D Thiagarajan model, by three stages of development: defining, designing, and developing. The valid, practical, and effective data in the form of module assessment were analyzed by conversing the scores to the qualitative data on the scale of five, and the data on the effectiveness in the form of an evaluation test was analyzed with the percentage of the learning mastery and the increase in the students' achievement was analyzed using the normal gain score. The validity of the product can be seen from the result of two experts' validations that the product is very valid. The practicality of the product can be seen from teachers' assessment and students' assessment that the module is very practice. The effectiveness of the product can be seen from students attainment KKM score of 75 and the increase in the mastery learning show that the module is very effective. This shows that the module is proper to use as learning resource for SMK students.
\end{abstract}

Keywords: development, mathematics, SMK, module, open-ended problem 


\section{PENDAHULUAN}

Persaingan dalam dunia kerja, sebagai akibat dari globalisasi, menuntut sumber daya manusia (SDM) yang unggul dan berdaya saing. Hal ini sejalan dengan artikel yang diterbitkan Kementerian Sosial RI $(2007$, p.2) bahwa hanya bangsa-bangsa yang memiliki keunggulan kompetitif yang mengandalkan diri pada sumber daya manusia yang berkualitas dan menguasai ilmu pengetahuan dan teknologi yang akan berhasil meraih kemajuan dalam situasi global yang penuh dengan persaingan ketat. SDM yang unggul adalah SDM yang memiliki daya saing yang tinggi, inovatif, kreatif dan mampu menghadapi segala tantangan yang ada baik lokal, regional maupun global. SDM yang memiliki kualitas SDM yang demikian diharapkan mampu bersaing dalam menghadapi peluang dan tantangan di masa yang akan datang.

Sekolah Menengah Kejuruan (SMK) merupakan pendidikan kejuruan yang menyiapkan lulusan siap bersaing di dunia kerja. Misi dari SMK adalah menghasilkan lulusan yang memiliki jati diri bangsa dan keunggulan kompetitif di pasar nasional dan global. Akan tetapi, tingginya ekspektasi terhadap lulusan SMK ternyata tidak diimbangi dengan kenyataan akan keberhasilan mereka di dunia kerja. Hal ini terlihat pada laporan Badan Pusat Statistik (BPS) mengenai keadaan ketenagakerjaan di Indonesia tahun 2012.

Tabel 1. Tingkat Pengangguran Terbuka

Penduduk Usia 15 Tahun ke Atas menurut Pendidikan Tertinggi yang Ditamatkan, 20102012 dalam Persen

\begin{tabular}{lccccc}
\hline $\begin{array}{l}\text { Pendidikan } \\
\text { tertinggi } \\
\begin{array}{c}\text { yang } \\
\text { ditamatkan }\end{array}\end{array}$ & Feb & Agust & Feb & Agust & Feb \\
\hline SD ke & 3,71 & 3,81 & 3,37 & 3,56 & 3,69 \\
Bawah & & & & & \\
SMP & 7,55 & 7,45 & 7,83 & 8,37 & 7,80 \\
SMA & 11,90 & 11,90 & 12,17 & 10,66 & 10,34 \\
SMK & 13,81 & 11,87 & 10,00 & 10,43 & 9,51 \\
Diploma & 15,71 & 12,78 & 11,59 & 7,16 & 7,50 \\
Universitas & 14,24 & 11,92 & 9,95 & 8,02 & 6,95 \\
Jumlah & 7,41 & 7,14 & 6,80 & 6,56 & 6,32 \\
\hline
\end{tabular}

Berdasarkan Tabel 1, diketahui bahwa pada Februari tahun 2012, Tingkat Pengangguran Terbuka (TPT) untuk pendidikan menengah masih tetap menempati posisi tertinggi, yaitu TPT Sekolah Menengah Atas sebesar 10,34\% dan TPT Sekolah Menengah Kejuruan sebesar 9,51\% (BPS, 2012, p.5). Fakta tersebut menun- jukkan bahwa masih ada yang kurang dalam pelaksanaan pendidikan di SMK sehingga realita belum sesuai dengan visi misi SMK.

Proses pendidikan yang hanya berupa transfer ilmu pengetahuan saja tidaklah cukup untuk membentuk pribadi yang unggul. Hal ini sejalan dengan pendapat Slavin (2006, p.4) yaitu "effective instruction is not a simple matter of one person with more knowledge transmitting that knowledge to another". Siswa juga harus dibekali dengan pengetahuan dan kemampuan dalam mengimplementasikan ilmunya di dalam masyarakat. Siswa perlu diajarkan tentang pengolahan informasi, interpretasi dan pemberian makna terhadap apa yang dipelajari. SDM yang diharapkan dapat memenuhi tantangan kemajuan serta persaingan yang bersifat global adalah mereka yang antara lain memiliki kemampuan berpikir secara kritis, logis, sistematis, dan kreatif sehingga mampu menghadapi berbagai permasalahan kehidupan secara mandiri dengan penuh rasa percaya diri.

Upaya mewujudkan kualitas SDM tersebut tentu saja tidak mungkin dilakukan melalui cara-cara lama yang cenderung mengandalkan proses pengembangan kemampuan yang lebih bersifat prosedural serta kurang memuat tantangan. Upaya tersebut perlu dikembangkan lebih jauh lagi sehingga menyentuh aspek-aspek yang memungkinkan seseorang mampu mengembangkan potensi yang dimilikinya secara optimal. Salah satu cara yang dapat dilakukan untuk mencapai tujuan tersebut adalah dengan mengembangkan pendidikan yang berfokus pada pengembangan kemampuan berpikir. Pengembangan kemampuan tersebut antara lain dapat dilakukan melalui matematika yang dapat mendorong pengembangan kemampuan berpikir siswa.

Matematika memiliki peranan yang sangat penting dalam berbagai dimensi kehidupan. Matematika merupakan ilmu universal yang mendasari perkembangan teknologi modern. Matematika mempunyai peran penting dalam berbagai disiplin dan memajukan daya pikir manusia. Matematika merupakan sarana komunikasi sains tentang pola-pola yang berguna untuk melatih berfikir logis, kritis, kreatif dan inovatif (Depdiknas, 2006, p.428). Kompetensi tersebut diperlukan agar siswa dapat memiliki kemampuan memperoleh, mengelola, dan memanfaatkan informasi untuk bertahan hidup pada keadaan yang selalu berubah, tidak pasti, dan kompetitif. Sejalan dengan hal tersebut, NCTM (2000, p.5) menyebutkan bahwa di dalam dunia yang terus 
berubah, mereka yang memahami dan dapat mengerjakan matematika akan memiliki kesempatan dan pilihan lebih banyak dalam menentukan masa depannya. Kemampuan dalam matematika akan membuka pintu untuk masa depan yang produktif. Lemah dalam matematika akan menjadikan pintu tersebut tertutup. Jadi wajar apabila matematika menjadi mata pelajaran wajib bagi semua jenjang pendidikan mengingat betapa pentingnya matematika.

Terkait dengan pengembangan kompetensi siswa, KTSP memiliki peran yang penting. KTSP adalah kurikulum operasional yang disusun dan dilaksanakan oleh masing-masing satuan pendidikan (Depdiknas, 2005, p.3). Salah satu prinsip pengembangan KTSP adalah berpusat pada potensi, perkembangan, kebutuhan, dan kepentingan siswa dan lingkungannya. Dalam hal ini, siswa memiliki posisi sentral untuk mengembangkan kompetensinya. Selain itu, substansi kurikulum mencakup keseluruhan dimensi kompetensi, bidang kajian keilmuan dan mata pelajaran yang direncanakan dan disajikan secara berkesinambungan antarsemua jenjang pendidikan. Hal ini sesuai dengan prinsip-prinsip dan standar matematika sekolah yang dikemukakan NCTM. Dengan demikian, diharapkan KTSP mampu memberikan sumbangan positif bagi tercapainya tujuan pembelajaran matematika.

Keberhasilan suatu kurikulum sangat tergantung pada pelaksanaan atau implementasinya. Jihad (2008, p.41) menyatakan sebaik apapun kurikulum secara tertulis (ideal curriculum) itu dirancang, namun apabila dalam pelaksanaannya (actual curriculum) tidak didukung oleh berbagai unsur maka akan sulit mencapai hasil yang diinginkan. Implementasi kurikulum merupakan sebuah proses yang berkesinambungan dalam suatu sistem. Keberhasilannya sangat tergantung pada kesinergian diantara komponen sistem yang terlibat didalamnya. Dalam hal ini, salah satu indikator keberhasilan suatu kurikulum adalah tercapainya tujuan pendidikan yang telah ditetapkan. Dengan demikian, keberhasilan dalam implementasi kurikulum khususnya pada pelajaran matematika adalah tercapainya tujuan pembelajaran matematika.

Berdasarkan tujuan pembelajaran matematika di SMK yang diusung KTSP, kemampuan yang hendak dicapai dalam pembelajaran matematika yaitu pemahaman, penalaran, pemecahan masalah, komunikasi, sikap menghargai matematika dan kemampuan menerapkan matematika (Depdiknas, 2006, p.429). Hal ini senada dengan standar proses yang dinyatakan oleh NCTM (2000, p.29) yaitu "problem solving, reasoning and proof, communication, connection, and representation". Penguasaan terhadap kelima kompetensi dasar tersebut dimaksudkan agar siswa mampu berpikir secara kritis, logis, sistematis, dan kreatif. Berdasarkan hal tersebut, pembelajaran matematika, penyajian materi, dan evaluasinya perlu mempertimbangkan kompetensi tersebut dalam rangka mencapai tujuan pembelajaran matematika.

Tabel 2. Data Hasil Ujian Nasional Matematika SMK tahun 2009-2011

\begin{tabular}{lcccccc}
\hline & \multicolumn{2}{c}{$\mathbf{2 0 0 9}$} & \multicolumn{2}{c}{$\mathbf{2 0 1 0}$} & \multicolumn{2}{c}{$\mathbf{2 0 1 1}$} \\
\hline & Nasional & Yogya & Nasional & Yogya & Nasional & Yogya \\
\hline Rata-rata & 7,47 & 7,73 & 7,44 & 7,1 & 7,67 & 7,59 \\
Terendah & 0,25 & 1,25 & 0,25 & 1,75 & 1 & 3,2 \\
tertinggi & 10 & 10 & 10 & 10 & 10 & 10 \\
Nilai $\geq 8$ & $43,53 \%$ & $54,71 \%$ & $41,2 \%$ & $33,66 \%$ & $46,53 \%$ & $44,45 \%$ \\
Nilai $>8$ & $56,47 \%$ & 45,29 & $58,8 \%$ & $66,34 \%$ & $53,47 \%$ & $55,55 \%$ \\
\hline
\end{tabular}

Data hasil nilai matematika siswa SMK pada Ujian Nasional (UN) dalam kurun waktu tiga tahun ditunjukkan pada Tabel 2. Prestasi siswa dalam mata pelajaran matematika masih tergolong rendah dengan ditunjukkan rata-rata nilai berkisar 7,52 secara nasional dan 7,47 pada Daerah Istimewa Yogyakarta. Selain itu, persentase siswa dengan perolehan nilai di bawah nilai 8,00 semakin tinggi dari tahun ke tahun dan rata-rata mencapai lebih dari $50 \%$ dari keseluruhan siswa. Berdasarkan data tersebut, prestasi siswa dalam mata pelajaran matematika masih perlu untuk ditingkatkan.

Berdasarkan survei lapangan di beberapa SMK di Yogyakarta diperoleh beberapa fakta berikut. Alokasi waktu untuk mata pelajaran matematika mendapat porsi yang relatif sedikit, khususnya pada kelompok SMK bidang seni, kerajinan, dan pariwisata yaitu tiga jam pelajaran tiap minggu. Apalagi pada siswa kelas XI diberlakukan praktik industri selama kurang lebih tiga bulan. Siswa tidak mendapatkan pelajaran selama praktik industri. Pihak sekolah juga tidak menyediakan bahan ajar atau semacam 
modul untuk dipelajari siswa selama praktik. Pelajaran baru akan disampaikan setelah siswa menyelesaikan praktik industri dengan sisa waktu yang sangat terbatas.

Berdasarkan hasil wawancara pada beberapa guru di SMKN 1 Kalasan, ditemukan beberapa kendala dalam pembelajaran di kelas. Guru mengalami kekurangan waktu untuk menyampaikan semua materi terutama pada semester dimana diberlakukan praktik industri tersebut. Hal ini mengakibatkan tidak semua materi tersampaikan secara mendalam dan bahkan ada yang terlewatkan. Meskipun demikian, siswa tidak mendapatkan tambahan jam pelajaran di luar kegiatan belajar mengajar (KBM). Guru hanya memberikan tugas rumah untuk beberapa materi yang belum sempat disampaikan akibat keterbatasan waktu tersebut. Akan tetapi tugas yang diberikan hanya sekumpulan soal-soal rutin untuk dikerjakan di rumah tanpa ada umpan balik maupun pembahasan di dalam atau di luar kelas. Hal ini mengakibatkan sulit bagi guru untuk mengontrol tingkat penguasaan siswa terhadap materi mengingat keberagaman tingkat kemampuan siswa.

Bahan ajar merupakan salah satu komponen penting dalam proses pembelajaran. Bahan ajar (Ditjen Dikti, 2008, p.6) merupakan seperangkat materi/substansi pelajaran yang disusun secara sistematis, menampilkan sosok utuh dari kompetensi yang akan dikuasai siswa dalam kegiatan pembelajaran. Dengan adanya bahan ajar memungkinkan siswa mempelajari suatu kompetensi atau kompetensi dasar secara runtut dan sistematis sehingga secara akumulatif mampu menguasai semua kompetensi secara utuh dan terpadu. Bahan ajar disusun dengan tujuan; (1) membantu siswa dalam mempelajari sesuatu; (2) menyediakan berbagai jenis pilihan bahan ajar; (3) memudahkan pendidik dalam melaksanakan pembelajaran; serta (4) agar kegiatan pembelajaran menjadi lebih menarik. Terkait dengan keberagaman kemampuan dan kondisi siswa, perlu diperhatikan bahan ajar yang mampu memfasilitasi keberagaman tersebut dan disesuaikan dengan kebutuhan siswa.

Ketersediaan sumber belajar matematika di SMKN 1 Kalasan masih terbatas. Siswa tidak menggunakan buku ajar, LKS, maupun buku referensi yang terkait dengan matematika. Siswa hanya belajar dari penjelasan dan catatan dari guru, serta bahan ajar semacam modul yang berisi uraian materi secara singkat dan soal-soal latihan. Uraian materi berisi rincian materi secara garis besar tanpa ada penjelasan atau deskrip- si yang mengarahkan siswa untuk memahami konsep. Soal-soal yang digunakan masih sebatas soal-soal rutin yang juga belum sepenuhnya mengembangkan kemampuan berpikir siswa. Berdasarkan hal tersebut, Penyediaan sumber belajar dalam bentuk bahan ajar yang sistematis dan mampu mengatasi semua keterbatasan tersebut merupakan hal yang perlu dikaji lebih lanjut.

Modul merupakan bahan ajar cetak dalam pembelajaran mandiri dengan topik yang terintegrasi (Dick, Carey, \& Carey (2001, p.9). Modul tersebut berisi informasi yang dibutuhkan siswa untuk mencapai dan menilai pengetahuan dan kemampuan tertentu. Lebih lanjut Ditjen Dikti (2008, p.4) menyatakan modul merupakan alat atau sarana pembelajaran yang berisi materi, metode, batasan-batasan, dan cara mengevaluasi yang dirancang secara sistematis dan menarik untuk mencapai kompetensi yang diharapkan sesuai dengan tingkat kompleksitasnya.

Salah satu tujuan dari penulisan modul (Ditjen Dikti, 2008, pp.5-6) adalah untuk mengatasi keterbatasan waktu, ruang dan daya indera, baik siswa maupun guru. Modul juga dapat memperjelas dan mempermudah penyajian pesan agar tidak terlalu bersifat verbal. Selain itu, modul juga dapat digunakan secara tepat dan bervariasi, seperti untuk meningkatkan motivasi dan gairah belajar; mengembangkan kemampuan dalam berinteraksi langsung dengan lingkungan dan sumber belajar lainnya yang memungkinkan siswa belajar mandiri sesuai kemampuan dan minatnya. Sebuah modul bisa dikatakan baik dan menarik apabila terdapat karakteristik, yaitu self instructional, self contained, stand alone, adaptive, dan user friendly (Ditjen Dikti, 2008, pp.4-5). Akan tetapi, modul yang digunakan pun ternyata masih terbatas dan belum mendukung dalam pencapaian kompetensi yang hendak dicapai dalam KTSP.

Permasalahannya sekarang adalah modul yang seperti apa yang sesuai dengan KTSP. Dalam Depdiknas (2006, p.428) menyebutkan bahwa mata pelajaran matematika perlu diberikan kepada semua siswa mulai dari sekolah dasar untuk membekali siswa dengan kemampuan berpikir logis, analitis, sistematis, kritis, dan kreatif, serta kemampuan bekerja sama. Aspek-aspek yang ditekankan dalam KTSP diantaranya yang sangat strategis adalah kemampuan siswa dalam memecahkan permasalahan dan mengkomunikasikan gagasan-gagasan matematik. Artinya, modul yang bercirikan KTSP adalah modul yang tidak hanya memuat masalah-masalah rutin akan tetapi masalah yang mampu mengembangkan 
kemampuan berpikir matematis, serta dapat menumbuhkembangkan kecakapan siswa dalam memecahkan permasalahan dan mengkomunikasikan gagasan-gagasan matematik.

Pendekatan open-ended merupakan salah satu upaya inovasi pendidikan matematika yang pertama kali dilakukan oleh para ahli pendidikan matematika Jepang. Jihad (2008, p.148) menyatakan bahwa pendekatan open ended adalah pendekatan yang menekankan pada soal aplikasi yang memungkinkan banyak solusi dan strategi. Pendekatan ini banyak mengeksplorasi kemampuan anak dalam mempelajari matematika. Pendekatan open-ended menjanjikan kepada suatu kesempatan kepada siswa untuk meginvestigasi berbagai strategi dan cara yang diyakininya sesuai dengan kemampuan mengelaborasi permasalahan. Tujuannya tiada lain adalah agar kemampuan berpikir matematika siswa dapat berkembang secara maksimal. Selain itu, kegiatankegiatan kreatif dari setiap siswa terkomunikasi melalui proses pembelajaran. Inilah yang menjadi pokok pikiran pembelajaran dengan open ended, yaitu pembelajaran yang membangun kegiatan interaktif antara matematika dan siswa sehingga mengundang siswa untuk menjawab permasalahan melalui berbagai strategi.

Pendekatan open ended ini menurut Sawada (1997, pp.23-24) memiliki beberapa keunggulan yaitu sebagai berikut. (1) Siswa berpartisipasi lebih aktif dalam pembelajaran dan sering mengekspresikan idenya. (2) Siswa memiliki kesempatan lebih banyak dalam memanfaatkan pengetahuan dan keterampilan matematik secara komprehensif. (3) Siswa dengan kemapuan matematika rendah dapat merespon permasalahan dengan cara mereka sendiri. (4) Siswa secara intrinsik termotivasi untuk memberikan bukti atau penjelasan. (5) Siswa memiliki pengalaman banyak untuk menemukan sesuatu dalam menjawab permasalahan.

Jenis masalah yang digunakan dalam pembelajaran melalui pendekatan open-ended ini adalah masalah yang bukan rutin yang bersifat terbuka. Sedangkan dasar keterbukaanya (openness) dapat diklasifikasikan kedalam tiga tipe, yakni (a) Prosesnya terbuka (process is open), maksudnya adalah tipe soal yang diberikan mempunyai banyak cara penyelesaian yang benar; (b) Hasil akhir yang terbuka (end product are open), maksudnya tipe soal yang diberikan mempunyai jawaban benar yang banyak (multiple), dan (c) Cara pengembang lanjutannya terbuka (ways to develop are open).
Adapun tiga jenis permasalahan openended yang dikemukakan Sawada (1997, p.27) adalah sebagai berikut.

Pertama, menemukan hubungan. Dalam hal ini, siswa diberi pertanyaan untuk menemukan suatu aturan matematis atau relasi/hubungan. Kedua, mengklasifikasi. Siswa diberi pertanyaan untuk mengklasifikasi berdasarkan karakteristik-karakteristik yang berbeda dari beberapa objek tertentu untuk memformulasikan beberapa konsep matematis. Ketiga, menentukan ukuran. Siswa diberi pertanyaan untuk menemukan ukuran numeris berkaitan dengan fenomena yang diberikan. Permasalahan ini menuntut mereka mengaplikasikan pengetahuan matematis dan keterampilan yang mereka miliki untuk meyelesaikan permasalahan ini.

Pemanfaatan masalah terbuka (openended problem), yang merupakan fokus utama dalam pendekatan tersebut, pada penyusunan bahan ajar memberikan solusi alternatif terhadap pencapaian tujuan matematika. Masalah terbuka membantu mengembangkan kegiatan kreatif dan pola pikir matematik siswa melalui problem posing secara simultan. Siswa diarahkan untuk menggunakan pengetahuan awal dan keterampilan yang mereka miliki untuk menyelesaikan masalah. Dengan demikian diharapkan siswa akan mampu mengembangkan kemampuan berpikirnya.

Pengembangan modul yang berbasis pada open-ended problem tentunya akan mampu mengatasi permasalahan yang ada di SMK bidang seni, kerajinan, dan pariwisata. Modul yang dikembangkan terutama difokuskan pada semester yang rawan memiliki waktu yang terbatas, terutama saat dilaksanakan praktik industri. Berdasarkan hasil pengamatan dan wawancara, materi yang perlu untuk dikembangkan adalah pada standar kompetensi (SK) "menentukan kedudukan jarak, dan besar sudut yang melibatkan titik, garis, dan bidang dalam ruang dimensi dua”. Selain itu, penyajian modul matematika yang dikombinasikan dengan unsurunsur seni dan pariwisata beserta implementasinya diharapkan mampu memberikan pembelajaran yang lebih bermakna bagi siswa. yang Oleh karena itu, peneliti mengembangkan modul matematika SMK bidang seni, kerajinan, dan pariwisata yang berbasis open-ended problem sebagai implementasi KTSP. 


\section{METODE PENELITIAN}

\section{Jenis Penelitian}

Penelitian ini adalah penelitian pengembangan (development research). Peneliti menggunakan model pengembangan yang mengacu pada model four-D yang dikemukakan oleh Thiagarajan, Semmel, dan Semmel. Model pengembangan tersebut terdiri dari empat tahap (Thiagarajan, 1974, p.5) yaitu pendefinisian (define), perancangan (design), pengembangan (develop), dan penyebaran (disseminate).

\section{Waktu dan Tempat Penelitian}

Penelitian dilakukan pada bulan JanuariJuni 2013 yaitu pada semester genap tahun ajaran 2012/2013. Penelitian dilaksanakan di SMK Negeri 1 Kalasan.

\section{Subjek Penelitian}

Subjek uji coba adalah siswa SMKN 1 Kalasan. Uji coba untuk mengukur kelayakan instrumen tes hasil belajar (THB) yaitu siswa kelas XIIA untuk pretest dan posttest. Uji coba untuk mengukur kualitas produk yaitu sebanyak 5 siswa dari kelas XII Kayu A dan 3 guru matematika untuk uji coba I dan 32 siswa dari kelas XI Tekstil A untuk uji coba II.

\section{Prosedur Pengembangan}

Peneliti menggunakan model pengembangan yang mengacu pada model four- $D$ yang terdiri dari empat tahap yaitu pendefinisian (define), perancangan (design), pengembangan (develop), dan penyebaran (disseminate). Adapun komponen-komponen pada setiap tahap pengembangan modul adalah sebagai berikut. (1) Tahap Pendefinisian, meliputi analisis awalakhir, analisis siswa, analisis konsep, analisis tugas, dan spesifikasi tujuan pembelajaran; (2) Tahap Perancangan, meliputi penyusunan instrumen, pemilihan media, pemilihan format, dan rancangan awal modul; (3) Tahap Pengembangan, meliputi validasi ahli dan uji coba produk; (4) Tahap Penyebaran, meliputi pengemasan dan pendistribusian serta publikasi.

Modifikasi model four-D dalam pengembangan modul disajikan secara lebih operasional pada gambar 1 berikut.

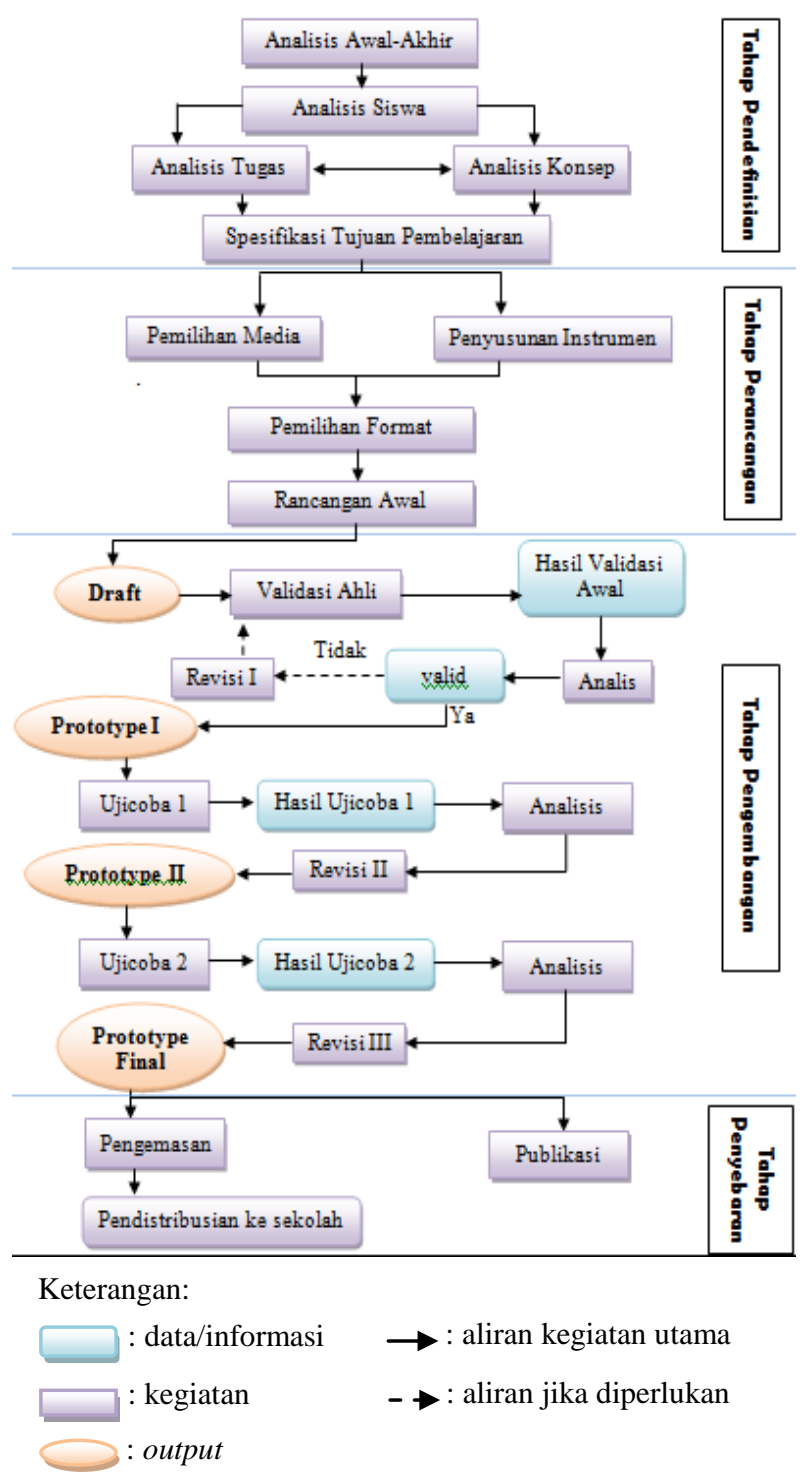

Gambar 1. Diagram Alir Pengembangan

Modul Modifikasi dari Model Four-D

\section{Data, Intrumen, dan Teknik Pengumpulan Data}

Teknik pengumpulan data dalam penelitian ini adalah tes dan non-tes. Data yang diperoleh dalam penelitian ini berupa data kuantitatif dan data kualitatif. Data kuantitatif diperoleh dari hasil tes awal (pretest) dan tes akhir (posttest). Data kualitatif diperoleh dari penilaian para ahli mengenai kelayakan instrumen, data validasi mengenai kevalidan produk, dan data penilaian guru dan siswa terhadap kepraktisan dan keefektifan produk. Instrumen penelitian yang digunakan dikelompokkan berdasarkan aspek criteria kualitas produk sebagai berikut. 
Tabel 2. Instrumen Penelitian Berdasarkan

Kriteria Kualitas Produk yang Diukur

\begin{tabular}{ll}
\hline \multicolumn{1}{c}{$\begin{array}{c}\text { Kriteria } \\
\text { Kualitas }\end{array}$} & \multicolumn{1}{c}{ Instrumen } \\
\hline Kevalidan & Lembar validasi modul \\
Kepraktisan & $\bullet \quad$ Lembar penilaian kepraktisan \\
& modul dari guru \\
& Lembar penilaian keterbacaan \\
& modul dari siswa \\
& Lembar penilaian siswa \\
Keefektifan & $\begin{array}{l}\text { Tes hasil belajar (pretest dan } \\
\text { posttest) }\end{array}$ \\
\hline
\end{tabular}

\section{Teknik Analisis Data}

Data kevalidan dan kepraktisan berupa penilaian terhadap modul dianalisis dengan mengkonversi skor menjadi data kualitatif skala lima menggunakan ketentuan pada Tabel 3. Data keefektifan berupa tes hasil belajar dianalisis dengan persentase ketuntasan belajar dan peningkatan prestasi belajar siswa. Siswa dikatakan tuntas apabila memperoleh nilai perolehan minimal sama dengan KKM sekolah yaitu 75 . Peningkatan hasil belajar siswa dapat dilihat melalui nilai $N$-gain $(g)$. Rumus untuk menentukan $g$ sebagai berikut (Hake, 1998, p.65).

$$
g=\frac{S_{\text {post }}-S_{\text {pre }}}{S_{\text {maks }}-S_{\text {pre }}}
$$

Keterangan:

$N$-gain $(\mathrm{g})=$ gain yang dinormalisasi

$\mathrm{S}_{\text {pre }}=$ skor perolehan siswa pada tes awal (pretest)

$\mathrm{S}_{\text {post }}=$ skor perolehan siswa pada tes akhir (posttest)

$\mathrm{S}_{\text {maks }}=$ skor maksimum ideal

Tabel 3. Konversi Skor Aktual menjadi Nilai Skala Lima (Azwar, 2013, p.163)

\begin{tabular}{c|c}
\hline Interval Skor & Kategori \\
\hline $\mathrm{X}>\overline{\bar{X}}_{\mathrm{i}}+1_{2} 5 S B_{\mathrm{i}}$ & Sangat Baik \\
$\bar{X}_{\mathrm{i}}+0,5 S B_{\mathrm{i}}<\mathrm{X} \leq \bar{X}_{\mathrm{i}}+1_{s} 5 S B_{\mathrm{i}}$ & Baik \\
$\overline{\mathrm{X}}_{\mathrm{i}}-0,5 S B_{\mathrm{i}}<\mathrm{X} \leq \overline{\mathrm{X}}_{\mathrm{i}}+0,5 S B_{\mathrm{i}}$ & Cukup Baik \\
$\overline{\mathrm{X}}_{\mathrm{i}}-1_{2} 5 S B_{\mathrm{i}}<\mathrm{X} \leq \bar{X}_{\mathrm{i}}-0,5 S B_{\mathrm{i}}$ & Kurang Baik \\
$\mathrm{X} \leq \bar{X}_{\mathrm{i}}-1_{s} 5 S B_{\mathrm{i}}$ & Tidak Baik \\
\hline
\end{tabular}

Keterangan:

$\bar{X}_{i}=$ Rerata skor ideal $=1 / 2$ (skor maksimal ideal+ skor minimal ideal).

$S B_{i}=$ Simpangan baku ideal $=1 / 6$ (skor maksimal ideal -skor minimal ideal).

$\mathrm{XVM}=$ Skor aktual

Kategori kevalidan, kepraktisan, dan keefektifan modul dapat dilihat pada Tabel 4.

Tabel 4. Kategori Kevalidan, Kepraktisan, dan Keefektifan Modul

\begin{tabular}{|c|c|c|c|c|c|}
\hline \multicolumn{5}{|c|}{ Interval Skor } & \multirow{3}{*}{ Kategori } \\
\hline \multirow[t]{2}{*}{ Valid } & \multicolumn{3}{|c|}{ Praktis } & \multirow{2}{*}{$\begin{array}{c}\text { Efektif } \\
(\%)\end{array}$} & \\
\hline & PKG & PKAS & PKES & & \\
\hline$X>220$ & $X>15,75$ & $X>14,25$ & $X>9$ & $X \geq 90$ & Sangat V/P/E \\
\hline $183,33<\mathrm{X} \leq 220$ & $12,25<\mathrm{X} \leq 15,75$ & $11,08<\mathrm{X} \leq 14,25$ & $7<X \leq 9$ & $80 \leq X<90$ & $\mathrm{~V} / \mathrm{P} / \mathrm{E}$ \\
\hline $146,67<\mathrm{X} \leq 183,33$ & $8,75<\mathrm{X} \leq 12,25$ & $7,92<\mathrm{X} \leq 11,08$ & $5<X \leq 7$ & $65 \leq X<80$ & Cukup V/P/E \\
\hline $110<\mathrm{X} \leq 146,67$ & $5,25<\mathrm{X} \leq 8,75$ & $4,755<\mathrm{X} \leq 7,92$ & $3<x \leq 5$ & $50 \leq X<65$ & Kurang V/P/E \\
\hline$X \leq 110$ & $X \leq 5,25$ & $X \leq 4,75$ & $X \leq 3$ & $X \leq 50$ & Tidak V/P/E \\
\hline
\end{tabular}

Keterangan:

$\mathrm{X}=$ Skor aktual

$\mathrm{PKG}=$ penilaian kepraktisan oleh guru

PKAS = penilaian kepraktisan awal siswa

$\mathrm{PKES}=$ penilaian kepraktisan empiris siswa

$\mathrm{V} / \mathrm{P} / \mathrm{E}=\mathrm{valid} /$ praktis/efektif

\section{HASIL PENELITIAN DAN PEMBAHASAN}

\section{Hasil Pengembangan}

Produk yang dikembangkan dalam penelitian ini adalah modul matematika SMK bidang seni, kerajinan, dan pariwisata yang berbasis open-ended problem. Modul tersebut diharapkan dapat menjadi sumber belajar matematika yang mampu mengatasi masalah keterbatasan waktu, sumber daya, dan keberagaman kompetensi siswa SMK. Penelitian pengembangan ini telah dilakukan dengan mengacu kepada prosedur pengembangan model four- $D$ yang dikemukakan Thiagarajan, Semmel, \& Semmel. Aspek kualitas produk pengembangan berdasarkan kualitas produk Nieveen yang terdiri dari 3 aspek, yaitu valid, praktis, dan efektif.

Modul terdiri dari tiga bagian utama yaitu pendahuluan, isi/pembelajaran, dan bagian akhir. 
Bagian Pendahuluan

Bagian pendahuluan berisi deskripsi awal tentang modul, petunjuk penggunaan modul, komponen modul, dan garis besar isi modul (GBIM). Deskripsi awal memuat gambaran secara umum isi modul. Misalnya mendeskripsikan kegiatan belajar beserta kompetensinya secara ringkas, prasyarat kompetensi yang harus dikuasai siswa sebelum mempelajari modul, saran dalam mempelajari modul, dan informasi mengenai self assessment sebagai indikator penguasaan siswa terhadap kompetensi pada setiap kegiatan belajar. Petunjuk penggunaan modul memuat beberapa pedoman serta aturan dalam mempelajari modul. Bagian ini sangat penting mengingat modul merupakan sumber belajar siswa secara mandiri. Selain petunjuk bagi siswa, bagian ini juga memuat peranan guru dalam pembelajaran matematika menggunakan modul tersebut.

Komponen modul memuat beberapa icon penting beserta penjelasannya dalam modul. Icon ini dapat membantu siswa untuk mengenali bagian-bagian modul.

Garis besar isi modul (GBIM) memuat rincian isi modul yang disajikan dalam bentuk tabel. Bagian ini memuat kompetensi dasar (KD), indikator atau tujuan pembelajaran khusus, rincian kompetensi, dan teknik penilaian setiap kegiatan belajar (KB).

Bagian Isi/Pembelajaran

Bagian isi terdiri dari beberapa kegiatan belajar (KB). Masing-masing KB mencakup tujuan kegiatan pembelajaran, uraian materi, latihan-latihan beserta kunci jawabannya, tes formatif, dan umpan balik. Setiap KB diawali dengan semacam ilustrasi berupa gambar dan contoh aplikasi di kehidupan nyata dari konsep yang akan dipelajari. Ilustrasi ini diharapkan dapat memotivasi siswa sebelum masuk ke dalam setiap KB. Tujuan pembelajaran dituliskan kembali pada bagian awal KB sebagai gambaran kompetensi yang akan dikuasai siswa setelah mempelajari $\mathrm{KB}$ tersebut.

Modul yang dikembangkan memuat standar kompetensi (SK) tentang geometri dimensi dua, yaitu menentukan kedudukan, jarak, dan besar sudut yang melibatkan titik, garis, dan bidang dalam ruang dimensi dua. Modul ini terdiri atas tiga kegiatan belajar (KB) dimana masingmasing KB mencerminkan kompetensi dasar (KD) hasil penjabaran dari SK yang telah ditetapkan tersebut. Kegiatan belajar tersebut meli- puti KB 1 yang menjelaskan tentang mengidentifikasi sudut, KB 2 mengenai konsep keliling dan luas bangun datar, dan KB 3 yang menjabarkan tentang transformasi bangun datar yaitu translasi, refleksi, rotasi, dan dilatasi.

Modul ini dikembangkan dengan menggunakan masalah-masalah open-ended. Oleh karena itu soal-soal yang digunakan juga harus mencerminkan masalah open-ended dimana soal bisa memiliki strategi penyelesaian ataupun jawaban yang lebih dari satu.

Tipe soal open-ended yang digunakan meliputi tiga tipe soal, yaitu tipe menemukan hubungan, mengklasifikasi, dan menentukan ukuran. Setiap kegiatan belajar diusahakan memuat ketiga jenis soal tersebut. Masalah openended tidak hanya disajikan dalam bentuk soal latihan, akan tetapi juga disajikan dalam bentuk tugas-tugas serta kegiatan siswa.

Berikut ini beberapa contoh penggunaan masalah open-ended di dalam modul.

\section{Tipe Soal Menemukan Hubungan}

\section{Contoh:}

Soal pada tugas siswa 2.1 (KB 2, hal. 21)

:- - - -

\section{Bandingkan sifat-sifat persegi dengan sifat-}

i sifat pada persegipanjang. Apa yang dapat!

! kamu katakan dari hasil temuanmu? Laporkan hasilnya pada gurumu!

i

Soal pada latihan 2 nomor 4 (KB2, hal. 43)

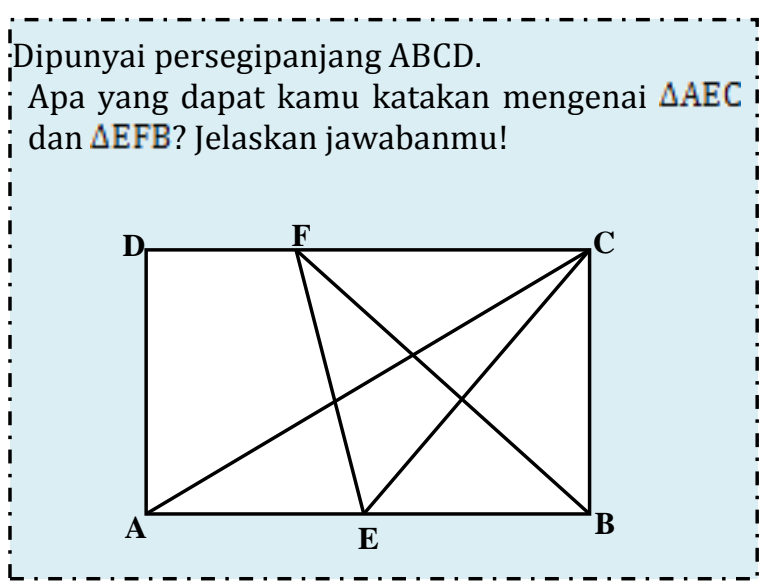


Soal pada latihan 3 nomor 8 (KB3, halaman 72)

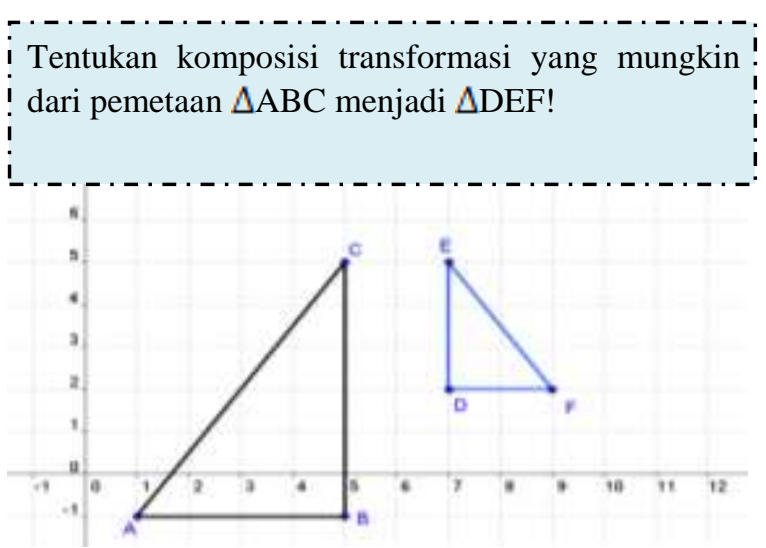

Tipe Soal Mengklasifikasi

Contoh:

Soal pada kegiatan siswa 1.1 (KB 1, hal.6)

1. Gambarlah beberapa sudut dengan ukuran berbeda!

2. Tentukan besar masing-masing sudut tersebut dengan menggunakan busur derajat!

3. Kelompokkan sudut-sudut tersebut berdasarkan kesamaan besar sudutnya. Ada berapa kelompok yang anda buat?

Soal pada kegiatan siswa 2.1 (KB 2, hal. 24)

1. Perhatikan gambar-gambar berikut.
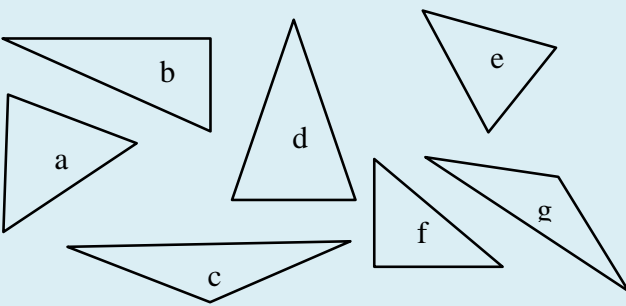

2. Ukurlah panjang sisi masing-masing segitiga tersebut!

3. Hal menarik apa yang dapat kamu temukan? Kelompokkan segitiga tersebut berdasarkan! kesamaan ciri yang kamu temukan.

i 4. Ukurlah besar sudut masing-masing segitiga tersebut!

5. Hal menarik apa yang dapat kamu temukan? Kelompokkan segitiga tersebut berdasarkan kesamaan ciri yang kamu temukan.

\section{Tipe Soal Menentukan Ukuran}

Contoh:

Soal pada latihan 1 nomor 6 (KB 1, hal. 13):

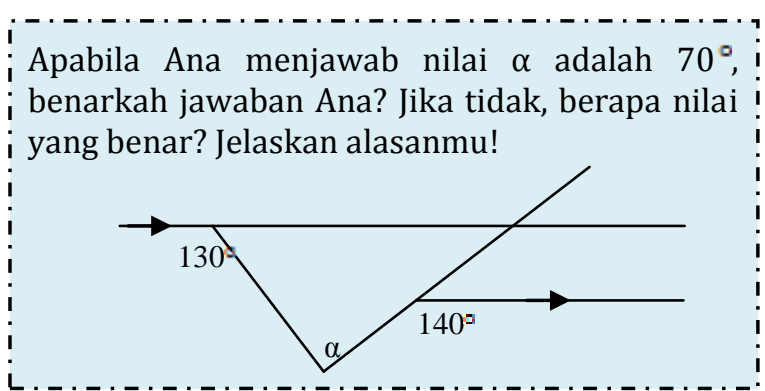

Soal pada latihan 2 no. 1d (KB 2, hal. 43) :

i Suatu persegipanjang dikombinasikan dengan i setengah lingkaran seperti pada gambar i berikut. Tentukan bangun datar yang memiliki i keliling yang sama dengan bangun datar ! tersebut! Suatu persegipanjang dikombinasikan ! dengan setengah lingkaran seperti pada gambar ! berikut. Tentukan bangun datar yang memiliki ! keliling yang sama dengan bangun datar tersebut!

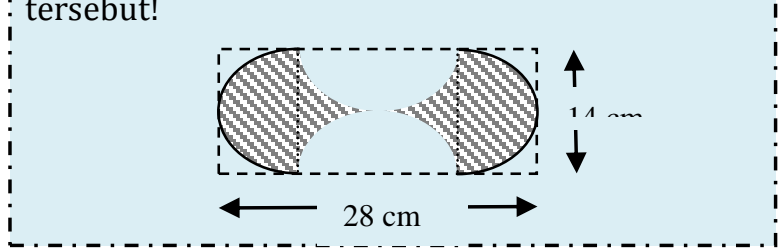

\section{Bagian Akhir}

Bagian akhir meliputi tes sumatif, kunci jawaban tes formatif dan sumatif, glosarium, dan daftar pustaka. Tes sumatif terdiri dari 30 soal pilihan ganda yang mencakup kompetensi yang harus dikuasai setelah mempelajari seluruh KB. Glosarium memuat beberapa istilah penting beserta keterangannya untuk mempermudah siswa memahami istilah tersebut.

\section{Hasil Analisis Data}

\section{Aspek Kevalidan Modul}

Seluruh skor yang diperoleh dari validator dijumlahkan menjadi skor aktual validasi modul (XVM). Modul dikatakan valid apabila penilaian dari validator menunjukkan XVM pada kategori minimal valid yaitu XVM > 201,67. Selain itu, modul dapat digunakan apabila pada kesimpulan instrumen dalam kategori LD atau LDR. Analisis data hasil validasi modul secara rinci disajikan pada Tabel 5 berikut. 
Tabel 5. Hasil Analisis Data Validasi Modul

\begin{tabular}{|c|c|c|c|c|c|c|c|c|}
\hline \multirow{2}{*}{ No } & \multirow{2}{*}{ Validator } & \multicolumn{4}{|c|}{ Skor Aktual/Aspek } & \multirow{2}{*}{$\mathbf{X V M}$} & \multirow{2}{*}{ Kategori } & \multirow{2}{*}{$\begin{array}{c}\text { Penilaian } \\
\text { Umum }\end{array}$} \\
\hline & & $\mathrm{A} 1$ & $\mathrm{~A} 2$ & $\mathrm{~A} 3$ & $\mathrm{~A} 4$ & & & \\
\hline 1 & V1 & 72 & 30 & 70 & 58 & 230 & SV & LDR \\
\hline 2 & V2 & 74 & 31 & 75 & 59 & 239 & SV & LDR \\
\hline \multicolumn{2}{|c|}{ Rata-rata } & 73 & 30,5 & 72,5 & 58,5 & 234,5 & SV & \\
\hline \multicolumn{2}{|c|}{ Kriteria Tiap Aspek } & SV & SV & SV & SV & & & \\
\hline
\end{tabular}

Keterangan:

$\mathrm{V} 1=$ validator $1, \mathrm{~V} 2=$ validator 2

$\mathrm{A} 1=$ isi $/$ materi, $\mathrm{A} 2=$ kebahasaan, $\mathrm{A} 3=$ penyajian, $\mathrm{A} 4=$ kegrafikan

$\mathrm{SV}=$ sangat valid

$\mathrm{LDR}=$ layak digunakan dengan revisi

$\mathrm{XVM}=$ skor aktual validasi modul

Data pada tabel 5 dapat dilihat bahwa skor aktual setiap validator $(\mathrm{XVM}) \geq 220$ sehingga setiap ahli menilai bahwa modul sangat valid. Begitupun hasil penilaian pada setiap aspek baik aspek isi/materi, kebahasaan, penyajian, dan kegrafikan juga masing-masing memenuhi kriteria sangat valid. Rata-rata hasil penilaian kedua ahli menyatakan modul juga sangat valid. Berdasarkan hal tersebut, dapat disimpulkan bahwa menurut penilaian para ahli secara keseluruhan modul yang dikembangkan dinyatakan memenuhi kriteria sangat valid. Penilaian secara umum berada pada kategori LDR sehingga masukan validator dijadikan dasar untuk perbaikan modul agar menjadi lebih sempurna.

Aspek Kepraktisan Modul

\section{Penilaian Guru terhadap Kepraktisan Modul}

Seluruh skor yang diperoleh dari penilaian guru dijumlahkan menjadi skor aktual kepraktisan dari guru (XKG). Hasil analisis data penilaian kepraktisan modul dari guru secara rinci disajikan pada Tabel 6 sebagai berikut.

Tabel 6. Hasil Analisis Data Penilaian Guru terhadap Kepraktisan Modul

\begin{tabular}{|c|c|c|c|c|c|c|c|}
\hline \multirow{2}{*}{ NO } & \multirow{2}{*}{$\begin{array}{l}\text { Guru } \\
\text { Penilai }\end{array}$} & \multicolumn{4}{|c|}{ Skor Tiap Aspek } & \multirow{2}{*}{ XKG } & \multirow{2}{*}{ Kategori } \\
\hline & & A1 & $\mathbf{A 2}$ & A3 & $\overline{A 4}$ & & \\
\hline 1 & G1 & 10 & 3 & 5 & 3 & 21 & SP \\
\hline 2 & $\mathrm{G} 2$ & 10 & 3 & 5 & 3 & 21 & SP \\
\hline 3 & G3 & 10 & 3 & 5 & 3 & 21 & SP \\
\hline \multicolumn{2}{|c|}{ Rata-rata } & 10 & 3 & 5 & 3 & 21 & SP \\
\hline \multicolumn{2}{|c|}{$\begin{array}{c}\text { Kriteria Tiap } \\
\text { Aspek }\end{array}$} & SP & SP & SP & SP & & \\
\hline
\end{tabular}

Keterangan:

G1/G2/G3 = guru penilai $1 / 2 / 3$

$\mathrm{A} 1=\mathrm{isi} /$ materi, $\mathrm{A} 2=$ kebahasaan, $\mathrm{A} 3=$ penyajian,

A4 = keterlaksanaan

$\mathrm{SP}=$ sangat praktis

$\mathrm{XKG}=$ skor aktual kepraktisan dari guru
Data pada Tabel 6 dapat dilihat bahwa skor aktual setiap guru $(\mathrm{XKG}) \geq 15,75$ sehingga masing-masing menilai bahwa modul sangat praktis. Begitupun hasil penilaian pada setiap aspek baik isi/materi, kebahasaan, penyajian, dan keterlaksanaan juga masing-masing memenuhi kriteria sangat praktis. Rata-rata penilaian ketiga guru menyatakan modul sangat praktis. Berdasarkan hal tersebut, dapat disimpulkan bahwa menurut penilaian guru secara keseluruhan modul yang dikembangkan dinyatakan memenuhi kriteria sangat praktis. Beberapa masukan dari guru dijadikan dasar untuk perbaikan modul agar menjadi lebih sempurna.

\section{Penilaian Kepraktisan Awal dari Siswa terhadap Modul}

Seluruh skor yang diperoleh dari penilaian siswa dijumlahkan menjadi skor aktual kepraktisan awal dari siswa (XKAS). Hasil analisis data penilaian kepraktisan awal dari siswa terhadap keterbacaan modul disajikan pada Tabel 7 sebagai berikut.

Tabel 7. Hasil Analisis Data Penilaian Kepraktisan Awal dari Siswa terhadap Keterbacaan Modul

\begin{tabular}{|c|c|c|c|c|c|c|c|}
\hline \multirow{2}{*}{ No } & \multirow{2}{*}{$\begin{array}{c}\text { Siswa Uji } \\
\text { coba }\end{array}$} & \multicolumn{4}{|c|}{ Skor Tiap Aspek } & \multirow{2}{*}{$\begin{array}{c}\text { XKA } \\
\text { S }\end{array}$} & \multirow{2}{*}{$\begin{array}{c}\text { Kategor } \\
\text { i }\end{array}$} \\
\hline & & A1 & A2 & A3 & A4 & & \\
\hline 1 & SU1 & 5 & 4 & 5 & 3 & 17 & SP \\
\hline 2 & SU2 & 6 & 3 & 4 & 2 & 15 & SP \\
\hline 3 & SU3 & 5 & 4 & 5 & 3 & 17 & SP \\
\hline 4 & SU4 & 6 & 4 & 5 & 3 & 18 & SP \\
\hline 5 & SU5 & 4 & 3 & 5 & 2 & 14 & $\mathrm{P}$ \\
\hline \multicolumn{2}{|c|}{ Rata-rata } & 5,20 & 3,60 & 4,80 & 2,60 & 16,20 & SP \\
\hline \multicolumn{2}{|c|}{ Kategori } & $\mathrm{P}$ & SP & SP & SP & & \\
\hline
\end{tabular}

Keterangan:

$\mathrm{SU}=$ subjek uji coba 
$\mathrm{A} 1=$ isi/materi, $\mathrm{A} 2$ = kebahasaan, $\mathrm{A} 3$ = penyajian, A4 $=$ keterlaksanaan

$\mathrm{SP}=$ sangat praktis, $\mathrm{P}=$ praktis

XKAS = skor aktual kepraktisan awal dari siswa

Data pada Tabel 7 dapat dilihat bahwa skor aktual penilaian kepraktisan awal empat siswa (XKAS) $\geq 14,25$ yang menunjukkan modul sangat praktis, sedangkan satu siswa menilai modul praktis. Apabila dikaji berdasarkan tiap aspek diperoleh aspek isi/materi berada pada kategori praktis sementara ketiga aspek lainnya dinilai sangat praktis. Hal ini kemungkinan karena masih terdapat kekurangan yaitu pada bagian isi/materi yang kurang jelas dan dianggap agak sulit untuk dipahami oleh siswa. Hal ini dijadikan dasar untuk merevisi modul agar lebih baik lagi. Rata-rata penilaian seluruh siswa menunjukkan bahwa modul berada pada kategori sangat praktis. Berdasarkan hal tersebut, dapat disimpulkan bahwa menurut penilaian siswa secara keseluruhan modul yang dikembangkan dinyatakan memenuhi kriteria sangat praktis.

\section{Penilaian Kepraktisan Empiris Siswa terhadap Modul}

Seluruh skor yang diperoleh dari penilaian siswa dijumlahkan menjadi skor aktual kepraktisan empiris dari siswa (XKES). Hasil analisis data penilaian kepraktisan modul dari siswa disajikan pada Tabel 8 sebagai berikut.

Tabel 8. Hasil Analisis Data Penilaian Kepraktisan Empiris Siswa

\begin{tabular}{cccccccc}
\hline \multirow{2}{*}{ No } & Kode & \multicolumn{7}{c}{ Skor Tiap Aspek } & \multirow{2}{*}{ XKES } & \multirow{2}{*}{ Kriteria } \\
\cline { 3 - 6 } & Siswa & A1 & A2 & A3 & A4 & & \\
\hline 1 & S-1 & 2 & 1 & 2 & 5 & 10 & SP \\
2 & S-2 & 2 & 2 & 2 & 5 & 11 & SP \\
3 & S-3 & 3 & 2 & 2 & 5 & 12 & SP \\
4 & S-4 & 2 & 1 & 2 & 5 & 10 & SP \\
5 & S-5 & 2 & 2 & 2 & 4 & 10 & SP \\
6 & S-6 & 2 & 1 & 2 & 5 & 10 & SP \\
7 & S-7 & 3 & 2 & 2 & 5 & 12 & SP \\
8 & S-8 & 3 & 2 & 2 & 5 & 12 & SP \\
9 & S-9 & 2 & 1 & 2 & 5 & 10 & SP \\
10 & S-10 & 2 & 2 & 2 & 5 & 11 & SP \\
11 & S-11 & 3 & 2 & 2 & 5 & 12 & SP \\
12 & S-12 & 3 & 2 & 2 & 5 & 12 & SP \\
13 & S-13 & 2 & 1 & 2 & 5 & 10 & SP \\
14 & S-14 & 3 & 2 & 2 & 5 & 12 & SP \\
15 & S-15 & 2 & 2 & 2 & 5 & 11 & SP \\
16 & S-16 & 2 & 0 & 2 & 5 & 9 & P \\
17 & S-17 & 2 & 2 & 2 & 4 & 10 & SP \\
18 & S-18 & 2 & 2 & 2 & 5 & 11 & SP \\
19 & S-19 & 2 & 2 & 2 & 5 & 11 & SP \\
20 & S-20 & 1 & 1 & 2 & 5 & 9 & P \\
21 & S-21 & 3 & 2 & 2 & 5 & 12 & SP \\
22 & S-22 & 3 & 2 & 2 & 5 & 12 & SP \\
\hline
\end{tabular}

\begin{tabular}{|c|c|c|c|c|c|c|c|}
\hline \multirow{2}{*}{ No } & \multirow{2}{*}{$\begin{array}{l}\text { Kode } \\
\text { Siswa } \\
\end{array}$} & \multicolumn{4}{|c|}{ Skor Tiap Aspek } & \multirow{2}{*}{ XKES } & \multirow{2}{*}{ Kriteria } \\
\hline & & A1 & $\mathbf{A 2}$ & $\mathbf{A 3}$ & A4 & & \\
\hline 23 & S-23 & 1 & 0 & 2 & 5 & 8 & $\mathrm{P}$ \\
\hline 24 & S-24 & 3 & 2 & 2 & 5 & 12 & SP \\
\hline 25 & S-25 & 3 & 2 & 2 & 5 & 12 & SP \\
\hline 26 & S-26 & 3 & 2 & 2 & 5 & 12 & SP \\
\hline 27 & S-27 & 2 & 2 & 2 & 5 & 11 & SP \\
\hline 28 & S-28 & 3 & 2 & 2 & 5 & 12 & SP \\
\hline 29 & S-29 & 3 & 2 & 2 & 5 & 12 & SP \\
\hline 30 & S-30 & 3 & 1 & 2 & 5 & 11 & SP \\
\hline 31 & $S-31$ & 3 & 2 & 2 & 5 & 12 & SP \\
\hline 32 & $\mathrm{~S}-32$ & 3 & 2 & 2 & 5 & 12 & SP \\
\hline \multicolumn{2}{|c|}{ Rata-rata } & 2,44 & 1,66 & 2,00 & 4,94 & 11,03 & SP \\
\hline \multicolumn{2}{|c|}{$\begin{array}{c}\text { Kriteria Tiap } \\
\text { Aspek }\end{array}$} & SP & SP & SP & SP & & \\
\hline
\end{tabular}

Keterangan:

$\mathrm{S}=$ subjek uji coba

$\mathrm{A} 1=$ isi/materi, $\mathrm{A} 2$ = kebahasaan, $\mathrm{A} 3$ = penyajian,

A4 = kemanfaatan

$\mathrm{SP}=$ sangat praktis, $\mathrm{P}=$ praktis

$\mathrm{XKES}=$ skor aktual kepraktisan empiris dari siswa

Data pada Tabel 8 menunjukkan bahwa bahwa hasil penilaian siswa menyatakan 29 dari 32 siswa atau 90,62\% siswa memberi penilaian pada kategori sangat praktis dan 3 siswa atau $6,25 \%$ menyatakan modul pada kategori praktis. Apabila ditinjau dari rata-rata perolehan skor tiap aspek maka diperoleh bahwa penilaian siswa pada setiap aspek juga memenuhi kriteria sangat praktis. Rata-rata penilaian seluruh siswa menunjukkan bahwa modul sangat praktis. Berdasarkan hal tersebut, maka dapat dikatakan bahwa modul yang dikembangkan sangat praktis.

\section{Aspek Keefektifan Modul}

Data diperoleh dengan menggunakan THB yang telah divalidasi dan diuji coba kelayakannya. THB diberikan pada kelas uji coba yaitu kelas XI Tekstil A sebanyak 32 siswa.

\section{Kriteria Ketuntasan Minimal (KKM)}

Kriteria keefektifan ditinjau dari persentase siswa yang tuntas atau mencapai nilai KKM yaitu 75 dapat dilihat pada Tabel 9.

Tabel 9. Hasil Analisis Aspek Ketuntasan KKM Data Hasil THB Siswa

\begin{tabular}{lcccc}
\hline & \multicolumn{4}{c}{ Ketuntasan } \\
\cline { 2 - 5 } & Tidak Tuntas & $\%$ & Tuntas & $\%$ \\
\hline Pretest & 32 & 100 & 0 & 0,00 \\
Postest & 3 & 9,38 & 29 & 90,62 \\
\hline
\end{tabular}

Hasil analisis pada tabel 9 menunjukkan bahwa ketuntasan klasikal mencapai 90,62\%. 
Hal ini menunjukkan bahwa modul yang dikembangkan memenuhi kriteria sangat efektif.

\section{Peningkatan Hasil Belajar}

Kriteria keefektifan ditinjau dari peningkatan hasil belajar pada Tabel 10 .

Tabel 10. Hasil Analisis Peningkatan Hasil

Belajar Siswa Berdasarkan Kategori Nilai $N$ gain

\begin{tabular}{cccccccc}
\hline & \multicolumn{6}{c}{$N$-gain } \\
\cline { 2 - 7 } & Rendah & $\%$ & Sedang & $\%$ & Tinggi & \% \\
\hline $\begin{array}{c}\text { Banyak } \\
\text { Siswa }\end{array}$ & 3 & 9,37 & 23 & 71,88 & 6 & 18,74 \\
\hline
\end{tabular}

Kriteria keefektifan ditinjau dari peningkatan hasil belajar pada Tabel 10 menunjukkan bahwa $71,88 \%$ dari keseluruhan siswa berada pada kategori sedang dan $18,74 \%$ siswa pada kategori tinggi. Persentase siswa yang menunjukkan peningkatan hasil belajar mencapai $90,62 \%$. Hal ini menunjukkan bahwa modul yang dikembangkan memenuhi kriteria sangat efektif.

\section{SIMPULAN DAN SARAN}

\section{Simpulan}

Berdasarkan pertanyaan penelitian dan hasil penelitian yang telah diuraikan, diperoleh kesimpulan sebagai berikut. Pertama, dihasilkan prototiping pengembangan modul matematika SMK berbasis open-ended problem yang memenuhi kriteria valid, praktis, dan efektif yakni; (a) tahap pendefinisian yang meliputi analisis awalakhir, analisis siswa, analisis konsep, analisis tugas, dan spesifikasi tujuan pembelajaran; (b) tahap perancangan yang meliputi penyusunan instrumen, pemilihan media, pemilihan format, dan rancangan awal modul; (c) tahap pengembangan yang meliputi validasi ahli dan uji coba. Tahap uji coba produk terdiri dari tahap uji coba I dan uji coba II.

Kedua, dihasilkan modul Matematika SMK bidang seni, kerajinan, dan pariwisata berbasis open-ended problem yang memenuhi kriteria valid, praktis, dan efektif. (1) tingkat kevalidan yakni 2 ahli pembelajaran matematika menyatakan modul yang dihasilkan sangat valid; (2) Tingkat kepraktisan yakni: (a) hasil penilaian kepraktisan modul dari guru menyatakan modul sangat praktis untuk digunakan dalam pembelajaran matematika, (b) hasil penilaian kepraktisan awal dari siswa menyatakan modul sangat praktis, dan (c) hasil penilaian ke- praktisan awal dari siswa menyatakan modul sangat praktis; (3) tingkat keefektifan yakni: (a) hasil pencapaian KKM sangat efektif yaitu 90,62\% siswa mencapai nilai KKM, (b) peningkatan hasil belajar siswa menunjukkan modul sangat efektif yaitu $90,62 \%$ siswa menunjukkan peningkatan hasil belajar pada kategori sedang dan tinggi.

\section{Saran}

Berdasarkan kesimpulan yang dikemukakan tersebut, maka beberapa saran yang perlu dipertimbangkan untuk peningkatan kualitas pembelajaran matematika sekolah sebagai berikut. Guru disarankan untuk memanfaatkan modul matematika yang dikembangkan sebagai salah satu bahan ajar dalam pembelajaran matematika di sekolah. Selain itu, produk yang dikembangkan ini dapat dijadikan sebagai contoh pembelajaran matematika di SMK yang menggunakan masalah-masalah open-ended.

Diseminasi dan Pengembangan Produk Lebih Lanjut

Beberapa hal yang perlu dipertimbangkan untuk diseminasi dan pengembangan produk lebih lanjut adalah sebagai berikut. Modul yang dikembangkan dapat didistribusikan serta digunakan pada ruang lingkup yang lebih luas, yaitu SMK bidang seni, kerajinan, dan pariwisata yang lain. Hasil pengembangan dipublikasikan dan diseminarkan sehingga diharapkan dapat menjadi masukan bagi guru-guru SMK lainnya. Modul yang dikembangkan hanya terbatas pada aspek geometri dimensi dua, maka disarankan kepada peneliti lain untuk mengembangkannya pada ruang lingkup mata pelajaran matematika yang lain. Selain itum modul dapat dikembangkan lebih lanjut dengan mengkombinasikannya dengan pendekatan ataupun model pembelajaran yang lain.

\section{DAFTAR PUSTAKA}

Azwar, S. (2013). Tes prestasi: fungsi dan pengembangan pengukuran prestasi belajar. Yogyakarta: Pustaka Pelajar.

BPS. (7 Mei 2012). Berita resmi statistik no. 33/05/th. XV. Diambil pada tanggal 10 November 2012 dari http://www.bps.go.id/brs_file/naker_07 mei12.pdf.

Depdiknas. (2005). Peraturan Pemerintah Nomor 19 Tahun 2005, tentang Standar Nasional Pendidikan. 
Depdiknas. (2006). Peraturan Menteri Pendidikan Nasional Nomor 22 Tahun 2006, tentang Standar Isi.

Dick, W., \& Carey, L. (2001). The systematic design of instruction. London: Longman.

Ditjen Dikti. (2008). Penulisan modul. Diambil pada tanggal 6 November 2012 dari http://lpmpjogja.org/materi/fsp/2009Pembekalan-Pengawas/26\%20--20 KODE\%20--\%2005\%20-\%20A2\%20$\% 20 B \% 20$ Penulisan\%20 Modul.pdf

Hake, R. R. (1998). Interactive-engagement versus traditional methods: a six-thousandstudent survey of mechanics tests data for introductory physics course. Am. J. Phys., Vol 66, No 1, January 1998, 6474.

Jihad, A. (2008). Pengembangan kurikulum matematika (tinjauan teoritis dan historis. Yogyakarta: Multi Pressindo.
Kementerian Sosial. (24 Agustus 2007). Karakteristik SDM di masa mendatang: peluang dan hambatan. Diambil pada tanggal 11 November 2012 dari http://www.kemsos.go.id/modules.php?n ame $=$ News $\&$ file $=$ article $\&$ sid $=463$.

NCTM. (2000). Principles and standards for school mathematics. Reston: NCTM, Inc.

Sawada, T. (2005). Developing Lesson Plans. Dalam Becker, J. \& Shimada, S (Eds). The open-ended approach: a new proposal for teaching mathematics (pp. 1-9). Reston: NCTM.

Slavin, R. E. (2006). Educational psychology: theory and practice $\left(8^{\text {th }} \mathrm{ed}\right)$. Boston: Pearson Education, Inc.

Thiagarajan, S., Semmel, D., \& Semmel, M. (1974). Instructional development for training teachers of exceptional children : a sourcebook. Minnesota: CEC. 